\title{
Pulse Pressure Initial and Arterial Pressure Mean as A Prognostic Death Information in Acute Myocardial Infarction Patients
}

\author{
Budi Patria Meilus'), Kuncoro Bayu Aji'1), Trisulo Wasyanto',2) \\ 1)Department of Cardiovascular, Faculty of Medicine, Universitas Sebelas Maret \\ ${ }^{2)}$ Dr. Moewardi Hospital, Surakarta
}

\begin{abstract}
Background: Arterial blood pressure is an easily get variable, including systolic blood pressure, diastolic blood pressure, mean arterial pressure (MAP) and pulse pressure (PP). Although the variable blood pressure has clinical importance in many cardiovascular diseases, the variable that has become the best predictor in clinical practice cannot be determined. The purpose of this study is to determine the prognostic value of PP and MAP at the start of hospitalization in patients with acute myocardial infarction (IMA).

Subject and Method: This was a retrospective cohort study conducted at cardiovascular intensive care unit, Dr. Moewardi Hospital, Surakarta, Central Java. A sample of 150 IMA patients from July 2013 to December 2013 was selected for this study. Blood pressure was measured the first time the patient arrives at the emergency unit to determine the value of PP and MAP. Then the patient was observed by looking at mortality during hospitalization as a final result. Basic characteristics data were analyzed using logistic regression and displayed in quartile form. The Kaplan-Meier curve was used to see mortality in each quartile. Cox proportional regression analysis was used to see the magnitude of the risk of variable PP, MAP and other variables on mortality.

Results: The highest mortality was found in the first quartile group of $P P(O R=1.81 ; p<0.001)$ and MAP $(\mathrm{OR}=1.69 ; \mathrm{p}<0.001)$. The Kaplan-Meier curve showed the first quartile of the two groups had the lowest survival, while the third highest quartile $(\mathrm{p}<0.001)$. The results of the cox analysis showed a decrease in mortality risk of 0.49 per increase in $\mathrm{PP}$ by $10 \mathrm{mmHg}$ ( $95 \% \mathrm{CI}=0.07$ to 1.00 ; $\mathrm{p}=0.044)$ and 0.31 each increase in MAP by $10 \mathrm{mmHg}(95 \% \mathrm{CI}=0.09$ to $0.53 ; \mathrm{p}=0.003)$.

Conclusions: Blood pressure measurement can produce two variables as predictors of mortality in IMA patients, namely PP and MAP. Low PP and MAP are associated with higher mortality during hospitalization in IMA patients.
\end{abstract}

Keywords: Pulse pressure, mean arterial pressure, acute myocardial infarction, mortality

\section{Correspondence:}

Budi Patria Meilus. Department of Cardiovascular, Faculty of Medicine, Universitas Sebelas Maret, Universitas Sebelas Maret, Jl. Ir. Sutami 36A, Surakarta 57126, Central Java.Email: budipatriamp@gmail.com. Mobile : +6281228355615.

\section{BACKGROUND}

Arterial blood pressure is an easily obtainable, routine examination that is always performed on all patients who come to the hospital either through the outpatient polyclinic or the emergency unit. From a blood pressure check, several variables were obtained, namely systolic and diastolic blood pressure, pulse pressure (PP) and mean arterial pressure (MAP). Aging will make changes from the cardiovascular system, including an increase in blood vessel stiffness. In fact, age is associated with an increase in blood pressure, especially systolic blood pressure, with a relatively mild diastolic increase. This will make the distance between systole and diastolic pressure wider (pulse pressure) (Nyhan et al., 2011). 
The elasticity of the arterial segment is not always constant, but depends on the pressure of the strain. The higher the strain pressure, the higher the recruitment of collagen fibers which will reduce its elasticity. The pressure of stretching blood vessels is determined by the mean arterial pressure. Blood pressure variables are very important in the clinical assessment of many cardiovascular diseases, but the variables as the best prognosis tool have not been clearly determined (El-Menyar et al., 2011; Nyhan et al., 2011).

The purpose of this study is to compare pulse pressure with mean arterial pressure as information on the prognosis of mortality in patients with acute myocardial infarction who entered the cardiac intensive care room.

\section{SUBJECT AND METHOD}

\section{Study Design}

Data were obtained from randomized retrospective studies, using information from the medical records of Dr. Moewardi hospital, Surakarta, Central Java.

\section{Study Samples}

A total of 150 data on patients entering the cardiovascular intensive care room of Dr. Moewardi hospital with the diagnosis of acute myocardial infarction was taken within a span of 6 months, from July 2013 to December 2013.

\section{Study Instruments}

Arterial blood pressure data were taken first when the patient was in the emergency room. Pulse pressure was obtained by reducing systolic blood pressure with diastolic, while the mean arterial pressure was obtained by the formula [(systolic blood pressure $)+(2 \mathrm{X}$ diastolic blood pressure)] / 3. The diagnosis of acute myocardial infarction was established in the presence of 2 of the following 3 conditions, (1) typical angina chest pain accompanied by (2) ST segment deviation and (3) increase in cardiac enzymes, both troponin I and CKMB. From the medical record, it was seen the mortality of patients within 7 days during hospitalization in cardiovascular intensive hospitals. Dr. Moewardi hospital, Surakarta, as an outcome. Patient characteristics data were analyzed using logistic regression and indicated in the quartile, both for PP and MAP. Survival analysis was conducted for 7 days of hospitalization in each quartile group using the Kapplan Meier curve. Cox proportional regression analysis was used to see how much influence PP, MAP and other patient data had on mortality. The effect size of PP and MAP was seen with an increase of 10 $\mathrm{mmHg}$.

\section{Research Ethics}

The research ethics include inside informed consent, identity confidentiality, and ethical clearance carried out in the DR. Moewardi hospital, Surakarta.

\begin{tabular}{l}
\hline RESULTS \\
Basic characteristic data from patients were \\
grouped into quartiles (four parts), both in \\
groups of PP (table 1) and MAP (table 2). \\
From the data obtained, from 150 patients, \\
123 patients were male and 27 patients \\
were the remaining women, aged $59.07+$ \\
12.22 years. Of the 150 patients 142 pati- \\
ents were diagnosed with myocardial \\
infarction with ST segment elevation \\
(STEMI) and 8 with myocardial infarction \\
without ST segment elevation (NSTEMI). \\
There were 49 patients with a history of \\
diabetes mellitus, 82 with a history of \\
hypertension and 93 with a history of \\
previous smoking. The average systolic \\
blood pressure is $124.62 \pm 33.58$ mmHg \\
and the average diastolic blood pressure is \\
$78.29 \pm 20.16$ mmHg. The mean hemo- \\
globin level was $13.11 \pm 1.73$ g d dl, creatin \\
$1.61 \pm 87$ mg / dl, urea $55.92 \pm 39.49$ mg /
\end{tabular}


Indonesian Journal of Medicine (2019), 4(2): 88-95

https://doi.org/10.26911/theijmed.2019.04.02.02

$\mathrm{dl}$, and albumin $4.12 \pm .68 \mathrm{~g} / \mathrm{dl}$. In the PP group patients with the most killip 4 were found in the first quartile of 19 patients with a total mortality of 17 patients.

Table 1. Sample Characteristics

\begin{tabular}{|c|c|c|c|c|c|c|}
\hline $\begin{array}{c}\text { Quartile of Pulse } \\
\text { pressure }\end{array}$ & $\mathbf{1}$ & 2 & 3 & 4 & Total & $\mathbf{p}$ \\
\hline $\begin{array}{l}\text { Pulse Pressure } \\
\text { range (mmHg) } \\
\text { Gender }\end{array}$ & $14-31$ & $32-44$ & $45-52$ & $52-93$ & & 0.161 \\
\hline Male & 30 & 33 & 33 & 27 & 123 & \\
\hline Female & 5 & 6 & 6 & 10 & 27 & \\
\hline Age (year) & $\begin{array}{l}63.54 \\
\pm 11.27\end{array}$ & $51.90 \pm 12.96$ & $\begin{array}{c}59.44 \pm \\
10.44\end{array}$ & $\begin{array}{c}62.03 \pm \\
11.03\end{array}$ & $\begin{array}{c}59.07 \pm \\
12.22\end{array}$ & 0.642 \\
\hline Diagnosis & & & 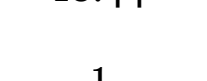 & -2.00 & - & 0.783 \\
\hline $\begin{array}{l}\text { NSETMI } \\
\text { STEMI }\end{array}$ & $\begin{array}{c}0 \\
35\end{array}$ & $\begin{array}{c}5 \\
34\end{array}$ & $\begin{array}{c}1 \\
38\end{array}$ & $\begin{array}{c}2 \\
35\end{array}$ & $\begin{array}{c}8 \\
142\end{array}$ & \\
\hline Diabetes Mellitus & 10 & 11 & 13 & 15 & 49 & 0.227 \\
\hline Hypertension & 22 & 20 & 16 & 24 & 82 & 0.929 \\
\hline $\begin{array}{l}\text { Smoking } \\
\text { Habit/history }\end{array}$ & 22 & 30 & 20 & 21 & 93 & 0.189 \\
\hline $\begin{array}{l}\text { Systolic pressure } \\
\text { (mmHg) }\end{array}$ & $\begin{array}{c}89.74 \pm 17 \\
.13\end{array}$ & $\begin{array}{c}115 \cdot 59 \pm 18.6 \\
5\end{array}$ & $\begin{array}{c}125 \cdot 38 \pm 15 \\
.02\end{array}$ & $\begin{array}{c}166.32 \pm \\
26.94\end{array}$ & $\begin{array}{c}124.62 \pm \\
33.58\end{array}$ & 0.001 \\
\hline $\begin{array}{l}\text { Diastolic } \\
\text { pressure (mmHg) }\end{array}$ & $\begin{array}{c}63.09 \pm 1 \\
4.23\end{array}$ & $77.74 \pm 17.99$ & $\begin{array}{c}77.23 \pm \\
14.68\end{array}$ & $\begin{array}{c}94.38 \pm \\
20.72\end{array}$ & $\begin{array}{c}78.29 \pm \\
20.16\end{array}$ & 0.001 \\
\hline $\begin{array}{l}\text { Mean Arterial } \\
\text { Pressure (mmHg) }\end{array}$ & $\begin{array}{c}72.06 \pm 14 \\
.95\end{array}$ & $\begin{array}{c}90.26 \pm 18.1 \\
6\end{array}$ & $\begin{array}{c}93.49+14 \\
81\end{array}$ & $\begin{array}{c}118.24+2 \\
2.39\end{array}$ & $\begin{array}{c}93 \cdot 75+23 \\
98\end{array}$ & 0.001 \\
\hline Killip grade & & & & & & 0.001 \\
\hline 1 & 13 & 23 & 19 & 24 & 79 & \\
\hline 2 & 3 & 8 & 16 & 9 & 36 & \\
\hline 3 & $\mathrm{O}$ & 5 & 1 & 4 & 10 & \\
\hline 4 & 19 & 3 & 3 & $\mathrm{o}$ & 25 & \\
\hline Death & 17 & 4 & 3 & 4 & 28 & 0.001 \\
\hline $\begin{array}{l}\text { Hemoglobin } \\
\text { (g/dl) }\end{array}$ & $\begin{array}{c}12.19 \pm 1.6 \\
9\end{array}$ & $13.30 \pm 1.54$ & $\begin{array}{c}13.45 \pm 1.7 \\
9\end{array}$ & $\frac{13.41 \pm 1.6}{6}$ & $13.11 \pm 1.73$ & 0.152 \\
\hline $\begin{array}{l}\text { Creatinine } \\
\text { (mg/dl) }\end{array}$ & $2.15 \pm 1.11$ & $1.56 \pm .79$ & $1.36 \pm .55$ & $1.43 \pm .77$ & $1.61 \pm .87$ & 0.001 \\
\hline Ureum (mg/dl) & $\begin{array}{c}86.71 \pm 54 \\
.23\end{array}$ & $\begin{array}{c}49.49 \pm 32.2 \\
2\end{array}$ & $\begin{array}{c}42.74 \pm 19 \\
36\end{array}$ & $\begin{array}{l}47.46 \pm 30 . \\
95\end{array}$ & $\begin{array}{l}55 \cdot 92 \pm 39 \\
49\end{array}$ & 0.001 \\
\hline Albumin (g/dl) & $3.66+.84$ & $4.11 \pm 0.60$ & $4.1 \pm .49$ & $4.58+.47$ & $4.12 \pm .68$ & 0.001 \\
\hline
\end{tabular}

From the Kapplan Meier curve in the PP group 1 quartile with a PP value between 14-31 mmHg had the highest 7-day mortality, followed by quartile 4 then quartile 2 , and the one with the highest survival rate was quartile 3 with PP value $45-52 \mathrm{mmHg}$ $(\mathrm{p}<0.001)$. Whereas in the MAP group, it was found that quartile 1 with an MAP
Whereas in the MAP group, the 4 most killip patients were also in the 1st quartile of 25 patients, with a total mortality of 17 patients. value of $37-77 \mathrm{mmHg}$ also had the greatest mortality in 7 days of hospitalization, followed by quartile 4 then quartile 2, and who had the largest survival rate also in quartile 3 with MAP $94-107$ mmHg (p $<0.001)$.

With proportional cox regression analysis, each increase in PP by $10 \mathrm{mmHg}$ 
will reduce the risk of death by 0.49 (95\% $\mathrm{CI}=0.07$ to $1.02 ; \mathrm{p}=0.044$ ), and each MAP increase of $10 \mathrm{mmHg}$ will reduce the risk of death by $0.31(95 \% \mathrm{CI}=0.09$ to $0.53 ; \mathrm{p}=$ o.003). Male sex will increase mortality risk by 3.34 (95\% $\mathrm{CI}=3.22$ to 3.47 ; $<0.001)$. The higher systolic blood pressure will reduce mortality by $0.03(95 \% \mathrm{CI}=$ 0.01 to $0.05 ; \mathrm{p}=0.014$ ), while the higher the diastolic blood pressure will reduce the mortality risk by 0.032 ( $95 \% \mathrm{CI}=0.01$ to o.06; $\mathrm{p}=0.016)$. The higher hemoglobin value will reduce mortality by 0.46 (95\% $\mathrm{CI}=0.28$ to $0.68 ; \mathrm{p}<0.001)$. The lower creatinin and urea values will reduce mortality by 0.90 ( $95 \% \mathrm{CI}=0.73$ to 1.13 ; p $<0.001$ ) and 0.015 (95\% CI = 0.01 to 0.02 ; $\mathrm{p}<0.001)$. The level of albumin and the diagnosis of STEMI did not significantly affect mortality.

Table 2. Data on the basic characteristics of patients with quartiles from mean arterial pressure

\begin{tabular}{|c|c|c|c|c|c|c|}
\hline $\begin{array}{c}\text { Mean Arterial } \\
\text { Pressure Quartiles }\end{array}$ & $\mathbf{1}$ & 2 & 3 & 4 & Total & $\mathbf{p}$ \\
\hline $\begin{array}{l}\text { Mean Arterial } \\
\text { pressure Range } \\
(\mathrm{mmHg})\end{array}$ & $37-77$ & $78-93$ & $94-107$ & $108-164$ & & \\
\hline Gender & & & & & & 0.192 \\
\hline Male & 31 & 33 & 32 & 27 & 123 & \\
\hline Female & 6 & 4 & 8 & 9 & 27 & \\
\hline Age (years) & $\begin{array}{l}60.16 \pm \\
14.746\end{array}$ & $\begin{array}{c}56.89 \pm \\
13.59\end{array}$ & $\begin{array}{c}58.33^{ \pm} \\
9.74\end{array}$ & $\begin{array}{l}61.03 \pm \\
10.29\end{array}$ & $\begin{array}{c}59.07 \pm \\
12.22\end{array}$ & 0.675 \\
\hline Diagnosis & & & & & & 0.049 \\
\hline NSTEMI & 0 & $\mathrm{O}$ & 6 & 2 & 8 & \\
\hline STEMI & 37 & 37 & 34 & 34 & 142 & \\
\hline Diabetes Mellitus & 10 & 11 & 14 & 14 & 49 & 0.237 \\
\hline Hypertension & 22 & 18 & 22 & 20 & 82 & 0.888 \\
\hline Smoking history & 25 & 17 & 25 & 26 & 93 & 0.404 \\
\hline $\begin{array}{l}\text { Systolic pressure } \\
\text { (mmHg) }\end{array}$ & $\begin{array}{l}84.49 \pm \\
11.46\end{array}$ & $\begin{array}{c}116.41 \pm \\
12.08\end{array}$ & $\begin{array}{c}128.20 \pm \\
7.09\end{array}$ & $\begin{array}{c}170.33 \pm \\
22.83\end{array}$ & $\begin{array}{c}124.62 \pm \\
33.58\end{array}$ & 0.001 \\
\hline $\begin{array}{l}\text { Diastolic pressure } \\
(\mathrm{mmHg})\end{array}$ & $\begin{array}{l}54.00 \pm \\
8.65\end{array}$ & $\begin{array}{c}71.03 \pm \\
6.41\end{array}$ & $\begin{array}{c}83.58 \pm \\
4.73\end{array}$ & $\begin{array}{c}104.86 \pm \\
12.18\end{array}$ & $\begin{array}{c}78.29 \pm \\
20.16\end{array}$ & 0.001 \\
\hline $\begin{array}{l}\text { Pulse Pressure } \\
(\mathrm{mmHg})\end{array}$ & $\begin{array}{l}30.49 \pm \\
9.51\end{array}$ & $\begin{array}{l}45.38 \pm \\
16.15\end{array}$ & $\begin{array}{l}44.63 \pm \\
8.79\end{array}$ & $\begin{array}{c}65.47 \pm \\
15.84\end{array}$ & $\begin{array}{c}46.33 \pm \\
17.77\end{array}$ & 0.001 \\
\hline Killip Grade & & & & & & 0.001 \\
\hline 1 & 8 & 27 & 23 & 21 & 79 & \\
\hline 2 & 2 & 8 & 15 & 11 & 36 & \\
\hline 3 & 2 & 2 & 2 & 4 & 10 & \\
\hline 4 & 25 & $\mathrm{O}$ & o & $\mathrm{O}$ & 25 & \\
\hline Death & 17 & 4 & 2 & 5 & 28 & 0.001 \\
\hline Hemoglobin (g/dl) & $\begin{array}{c}11.96 \pm \\
1.32\end{array}$ & $\begin{array}{c}13.80 \pm \\
1.69\end{array}$ & $\begin{array}{c}13.28 \pm \\
1.85\end{array}$ & $\begin{array}{c}13.39 \pm \\
1.49\end{array}$ & $\begin{array}{c}13.11 \pm \\
1.73\end{array}$ & 0.003 \\
\hline Creatinine (mg/dl) & $\begin{array}{c}2.22 \pm \\
1.07\end{array}$ & $1.42 \pm 0.60$ & $1.36 \pm 0.68$ & $1.47 \pm 0.80$ & $1.61 \pm 0.87$ & 0.001 \\
\hline Ureum (mg/dl) & $\begin{array}{c}88.35 \pm \\
50.82\end{array}$ & $\begin{array}{c}47.11 \pm \\
31.07\end{array}$ & $\begin{array}{c}43.23 \pm \\
23.79\end{array}$ & $\begin{array}{c}45 \cdot 75^{ \pm} \\
29.60\end{array}$ & $\begin{array}{c}55.92 \pm \\
39.49\end{array}$ & 0.001 \\
\hline Albumin (g/dl) & $\begin{array}{c}3.80 \pm \\
0.81 \\
\end{array}$ & $4.13 \pm 0.67$ & $\begin{array}{c}4.20 \pm \\
0.49 \\
\end{array}$ & $4.34 \pm 0.66$ & $4.12 \pm 0.68$ & 0.001 \\
\hline
\end{tabular}


Indonesian Journal of Medicine (2019), 4(2): 88-95

https://doi.org/10.26911/theijmed.2019.04.02.02

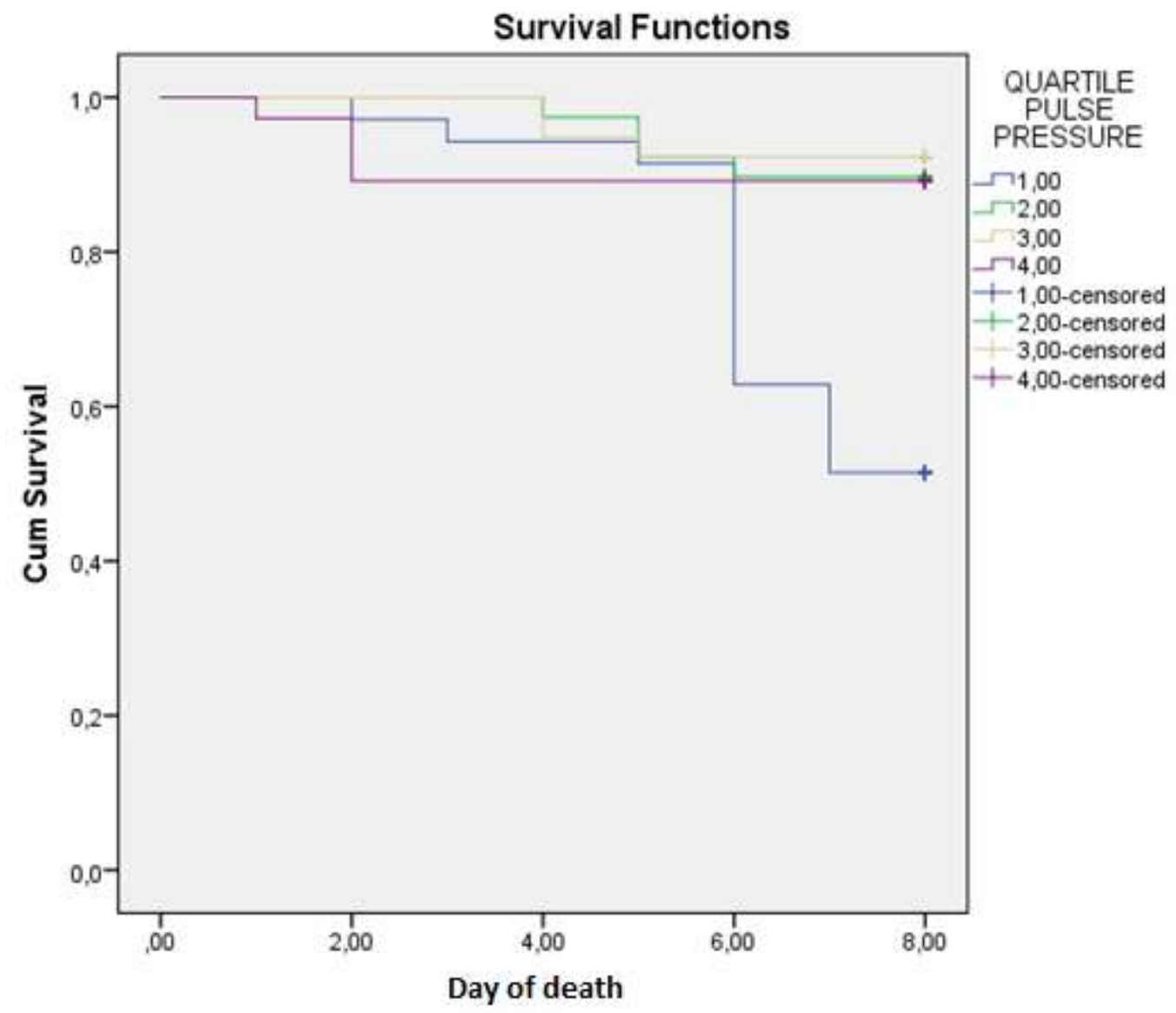

Figure 1. Kaplan Meier's curve in the PP quartile group

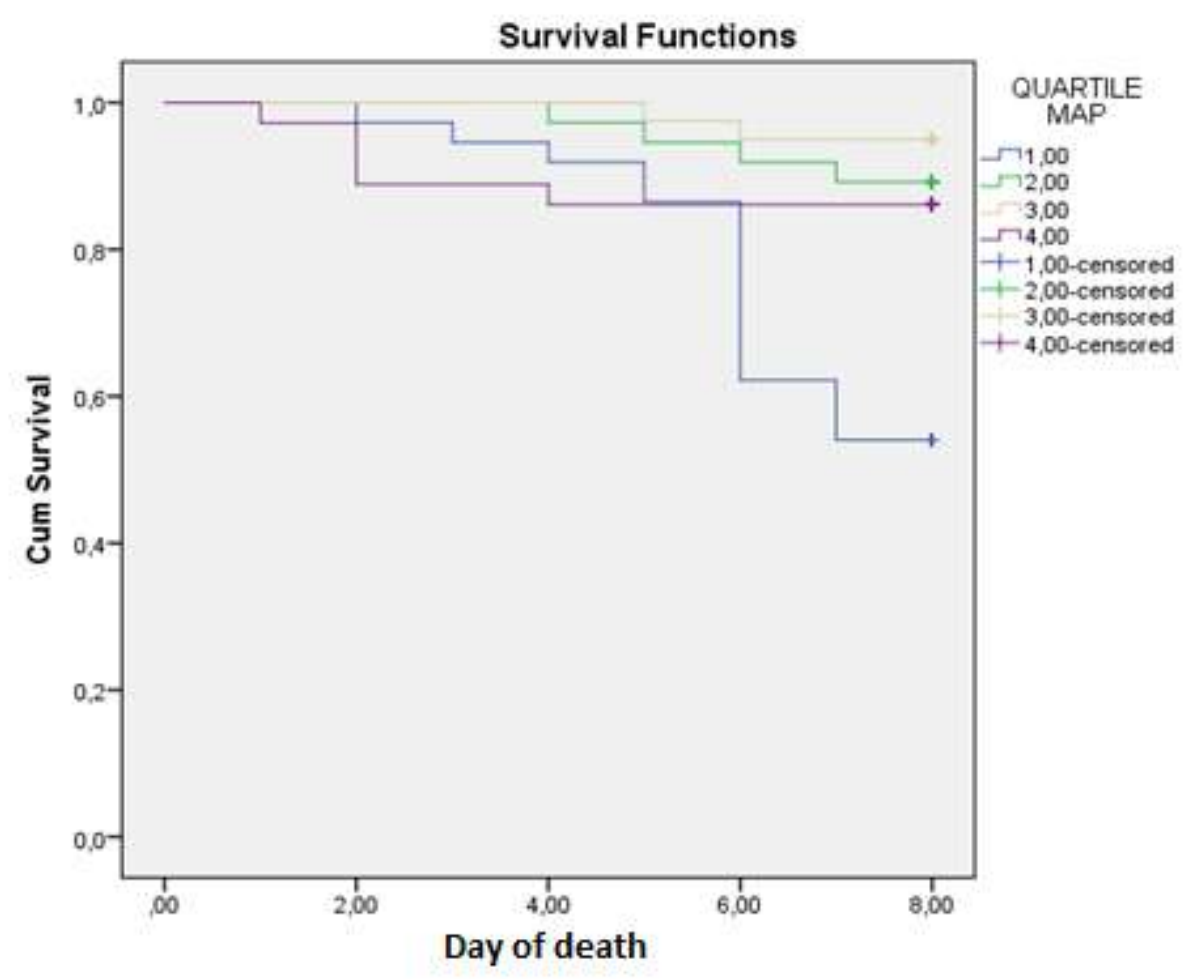

Figure 2. Kaplan Meier's curve in the MAP quartile group 
Table 3.Proportional Cox regression analysis

\begin{tabular}{lccc}
\hline \multicolumn{1}{c}{ Variable } & Hazard/Risk ratio & Limit risk ratio & p \\
\hline Pulse pressure (10 mmHg) & 0.49 & $0.07-1.02$ & 0.044 \\
Mean Arterial Pressure (10 & 0.31 & $0.09-0.53$ & 0.003 \\
mmHg) & & & \\
Male Gender & 3.34 & $3.22-3.47$ & $<0.001$ \\
Age & 0.06 & $0.04-0.10$ & $<0.001$ \\
Diabetes Mellitus & 0.23 & $0.56-1.16$ & 0.580 \\
Hypertension & 0.44 & $0.30-1.33$ & 0.225 \\
Smoking History & 0.65 & $0.10-1.77$ & 0.118 \\
Systolic Pressure & 0.03 & $0.01-0.05$ & 0.014 \\
Diatolic pressure & 0.03 & $0.01-0.06$ & 0.016 \\
Hemoglobin & 0.46 & $0.28-0.68$ & $<0.001$ \\
Creatinine & 0.90 & $0.73-1.13$ & $<0.001$ \\
Ureum & 0.02 & $0.01-0.02$ & $<0.001$ \\
Albumin & 0.51 & $0.11-1.06$ & 0.065 \\
STEMI & 3.09 & $2.53-3.34$ & 0.39 \\
\hline
\end{tabular}

\section{DISCUSSION}

This study shows the usefulness of one type of examination, namely blood pressure, which uses one kind of simple measurement tool, namely sphygmomanometer can produce two mortality prognosis parameters in patients with acute myocardial infarction, pulse pressure (PP) and mean arterial pressure (MAP).

The results of this study differ from previous studies which stated that high PP had a worse prognosis. However, in a previous study, the measurement of PP was not carried out at the beginning of hospital stays, measurements were made when the patient was out or 1 week post-infarction and evaluated after the patient was not at the hospital (Thomas et al., 2008). The results of this study found that the highest survival was owned by the third quartile PP with a PP value between $45-52 \mathrm{mmHg}$. The lowest PP group (quartile 1) had the highest mortality rate followed by the highest PP group (quartile 4). The PP value at the beginning of the stays that was too low or too high turned out to have a poor predictor value for mortality for 7 days of treatment in the hospital.

The pulse pressure value increased due to an increase in stiffness of the aorta. Stress that affected the walls of blood vessels would damage elastin which would reduce blood vessel compliance, and would get heavier with age. Other systemic diseases such as diabetes, hypertension, heart failure have a role in increasing blood vessel stiffness, as a result of accelerated damage to elastin, increased collagen buildup, smooth muscle mass and tone. Stiffness of blood vessels increased the aortic impedance/resistance to blood flow which has a periodic pattern, which would result in an increase in the amplitude of the pressure wave towards the front. The firmness of the arterial wall increased flow velocity, which triggered premature backflow of wave reflections from the periphery. This wave reflection then returned to the proximal aorta during the mid-late systolic phase, therefore, it would increase systolic pressure rather than diastolic. Increased stiffness of impure blood vessels was only due to structural abnormalities. Aorta and 
blood vessels contained a significant amount of muscle components in tunica media where increased sympathetic nerve activity would trigger vasoconstriction and increase blood vessel resistance and stiffness (Arnold et al., 1991; Domanski et al., 1999).

In another study it was found that low PP was also an independent predictor of stroke and mortality in IMA patients. Low PP was also an independent predictor of repeat ischemia in NSTEMI patients. Low PP during initial presentation was also a predictor of mortality during treatment in patients with IMA even without the incidence of heart failure. Heart failure due to ischemia with high PP was more due to the effects of atherosclerotics, while lower PP showed a dysfunction of the left ventricle (Petrie, Voors, and van Veldhuisen, 2009). Low PP when entering the hospital would specifically affect the outcome of hospitalization, which described the acute stress condition, while high PP has a poor prognosis in the long term, and a chronic case (Thomas et al., 2008). High PP would cause exacerbation of myocardial ischemia as a result of increased afterload and decreased coronary perfusion. While low PP indicated low stroke content and early signs of cardiogenic shock that may be associated with increased concentrations of natriuretic peptide (Petrie, Voors, and van Veldhuisen, 2009).

The study conducted by Petrie et al. (2012) reported that from 1959 patients in the first 21 days after infarction, only patients with 2-4 Killip classes who had low PP. Interestingly, lower PP was associated with higher troponin values and heart rate at rest. In low IMA, PP and MAP conditions it was a prognosis in STEMI and NSTEMI patients, even with normal systolic pressure. PP was a simple measurement method that can be part of the risk score assessment at IMA.

The highest mortality in the MAP group was also found in the quartile 1 group which had the lowest MAP value. Low MAP occurred in the condition of decreased cardiac output, which would cause neurohormonal activation which would lead to increased systemic vascular resistance and blood vessel stiffness (Franciosa et al., 1983). Low MAP indicated a dysfunction of the left ventricle. In a prospective study of 152 patients with NYHA II-IV heart failure showed a significant relationship between MAP and the NYHA class. The lower the MAP, the higher the NYHA class (Cleland, Dargie and Ford, 1987). In another prospective study with 182 samples, it was found that patients who died had lower MAP, which was associated with a decrease in cardiac output and an increase in systemic vascular resistance (Franciosa et al., 1983).

Based on the results of this study, it can be concluded that with a simple measurement of blood pressure, we can obtain two variables as predictors of death during hospitalization in IMA patients. This study showed that low PP and MAP would increase mortality during hospitalization in IMA patients. The values of PP and MAP that were too high also have a low survival curve. The optimal PP value was 45-52 mmHg and MAP 94-107 mmHg.

\footnotetext{
REFERENCES

Arnold JM, Marcgiori GE, Imrie JR, Burton Gl, Pflugfelder PW, Kostuk WJ (1991). Large artery function in patients with chronic heart failure. Studies of brachial artery diameter and hemodyna-mics. Circulation, 84: 2418-2425. doi: 10.1161/-01.CIR.84.6.-2418.

Cleland JG, Dargie HJ, Ford I (1987). Mortality in heart failure: clinical
} 
variables of prognostic value. $\mathrm{Br}$ Heart J, 58(6): 572-582.

DomanskiMJ, Mitchell GF, Norman JE, Exner DV, Pitt B (1999). Independent prognostic informa-tion provided by sphygmomanometri-cally determined pulse pressure and mean arterial pressure in patients with left ventricular dysfunction.J Am Coll Cardiol. 33(4): 951-958.

El-MenyarA, Zubaid M, Almahmeed W, Alanbaei M, Rshaed W, Qahtani AA, Singh R,et al. (2011). Initial hospital pulse pressure and cardiovascular outcomes in acute coronary syndrome. Archives of Cardiovas-cular Diseases. Elsevier Masson SAS, 104(8-9): 435-443. doi: 10.1016/j.acvd.2011.05.008.

Franciosa JA, Wilen M, Ziesche S, Cohn JN (1983). Survival in men with severe chronic left ventricular failure due to either coronary heart disease or idiopathic dilated cardiomyo-pathy. The American Journal of Cardiology, 51(5): 831-836. doi: 10.1016/-Sooo29149(83)80141-6.

Steppan J, Barodka V, Berkowitz DE, Nyhan D (2011). Vascular stiffness and increased pulse pressure in the aging cardiovascular system. Car-diology Research and Practice,1(1). doi: 10.4061/2011/263585.

Petrie CJ, Voors AA, Robertson M, van Veldhuisen DJ, Dargie HJ (2012). A low pulse pressure predicts mortality in subjects with heart failure after an acute myocardial infarction: A posthoc analysis of the CAPRICORN study. Clinical Research in Cardiology, 101(1): 29-35. doi: 10.-1007/so0392-011-0360-x.

Petrie CJ, Voors AA, van Veldhuisen DJ (2009). Low pulse pressure is an independent predictor of mortality and morbidity in non ischaemic, but not in ischaemic advanced heart failure patients. Int J Cardiol. 131(3): 336-44. doi: 10.1016/j.ijcard.2007.10.023 .

ThomasF, Blacher J, Benetos A, Safar ME, Pannier B (2008). Cardiovas-cular risk as defined in the 2003 European blood pressure classifica-tion: The assessment of an addi-tional predictive value of pulse pressure on mortality, Journal of Hypertension, 26(6): 1072-1077. doi: 10.1097/HJH.obo13e328-2fcc22b. 